\section{Soviet euphoria in wake of Venus probes}

from Vera Rich

THE success of the two Venus probes, Venera 9 and 10, the orbital sections of which are still gathering and transmitting data, has led to a spirit of selfcongratulation, not only among those concerned with the Venus mission, but throughout the Soviet space programme generally.

This success, coming as it does in the concluding months of the present five-year plan, and in a year already distinguished by the Salyut 4 and Soyuz-Apollo missions, will undoubtedly be a considerable incentive towards increasing the space budget in the next plan.

The economic justification for the Soviet space programme, as laid down by the Twenty-fourth Party Congress in 1971, is "to develop long range telephonic-telegraphic communications, television meteorological forecasting and the study of natural resources, geographical investigations and the solutions of other problems of the national economy with the aid of satellites, automatic and piloted spacecraft, and also to carry out fundamental scientific investigations of the Moon and planets of the solar system".

Although basic deep-space research does figure in this list, it seems that a need is felt to justify its importance (and cost) within the framework of the five-year plan. Accordingly, Pravda has highlighted not only the political significance of the Venus mission, which illustrates "how rapidly science and technology advances in conditions of socialism", but also the "terrestrial" aspect of the research carried out by the probes - by leading to a better understanding of planetary evolution, they will, it is suggested, facilitate the fuller utilisation of the natural resources of the Earth.

Pravda also carried an article from Professor A. Okhotin, of the Institute of Space Research, on the possibilities of carrying out technological processes in space. This idea has long been of interest to the Soviet space plannerspreliminary electron-beam welding and cutting experiments were carried out as long ago as Soyuz 6 in October 1969 -and two types of "space technology" are under consideration at present.

The first is the construction of large scale orbital space stations, for astronomical and geodetic observations, prospecting, weather forecasting and environmental surveillance. Tentative plans speak of stations with a mass of hundreds of tonnes and crews of several dozen. Such stations could be constructed "most economically" in orbit, and would also require a con- siderable amount of repair and refit technology for their successful long term operation.

The second type of space technology under discussion involves the processing and production, in conditions of weightlessness and vacuum, of materials which would be almost impossible to produce in terrestrial conditions. The materials would include exotic metal and metal-ceramic alloys, high purity glasses, and large single crystals of semiconductors. The cost involved would, of course, be considerable, but this, says Professor Okhotin, is not the issue. Since the results of the processes would be "unique", he argues, their costeffectiveness should not be a matter for discussion.

In the Soviet economy, where there is centralised budgetary control and planning, there is, theoretically, no need for any major expenditure to be justified to anyone beyond the higher echelons of Party or Government. Nevertheless, although no costs or estimates of the space programme have ever been published-except for vague hints that the cost of the Lunokhodbearing Moon probes, for example, is only half that of a manned missionthere has, over the years, been a considerable undercurrent of resentment against the enormous expenditure involved.

Kremlinologists have noticed that a number of 'black' jokes have circulated on the theme of 'pie in the sky', correlating achievements in space with food shortages at home. They note that a 'soft' campaign in the Press is standard Soviet practice in preparing the population for some new government drive or campaign.

This new concentration on the costeffectiveness of space research seems to suggest that, by forestalling possible criticism, next year's Party Congress will include in its "Theses" for the coming Five-year Plan a considerable extension of the Soviet space programme.

\section{Reprocessing 'scare' in Britain}

\section{by Allan Piper}

IF a backbench motion at present circulating around the Houses of Parliament gains sufficient support, the reprocessing of spent nuclear fuels in Britain may well be an issue to come under the scrutiny of the Select Committce on Science and Technology during the next Parliamentary session. The matter came to the fore a couple of weeks ago when some newspapers raised a furore over negotiations which could result in the transport of irradiated Japanese nuclear fuels to Britain for reprocessing at Windscale in Cumbria.

The Parliamentary moves may well have arisen directly from that publicity. But so far the initial press hysteria has signally failed to provoke any other reaction of conscquence, and even the 80 or so Members of Parliament who have already signed the motion-and who, according to some reports, can expect wide ministerial support-have chosen a sensibly judicious response to claims that Britain is in danger of becoming a "nuclear dustbin".

Most informed observers are agreed that such misplaced concern can only have sprung from a complete ignorance of both the probable terms of the eventual contract and the overall picture of the British nuclear industry. The deal, which could be worth $£ 300-500$ million to Britain, depends on Japanese agreement to take back an amount of waste equal to that produced by the reprocessing.

It is likely also that the British Government will insist that the contract include a clause releasing British Nuclear Fuels (BNFL), which owns the Windscale plant, from its obligations should it fail to develop a successful technique for vitrifying the radioactive waste.

So far the Japanese have shown no signs of baulking at those conditions, which effectively mean that even after the deal has gone through Britain will be left with no 'extra' waste. She will not in any case have to accept Japanese material unless a safe way of transporting its products is developed.

Moreover, the quantity of material which the Japanese will send to Britain $-4,000$ tonnes will be delivered to Windscale during the decade following 1979-is hardly significant even by comparison with the 1,500 tonnes already reprocessed annually in the UK. (A considerable proportion of this, incidentally, comes from British designed, first generation magnox reactors operating in Latina in Italy and Tukai Mura in Japan.)

Even if the quantity of Japanase material is considered on its own, the figures are rather misleading to the uninitiated: of the incoming 4,000 tonnes of irradiated fuel only some $3 \%$ eventually winds up as the potentially dangerous, waste fission products which have aroused the press. Of the rest, about $95 \%$ comes out as depleted uranium-which has virtually no radioactivity-and less than $1 \%$ becomes fissile plutonium, itself a useful nuclear fuel.

As both of those latter products have some utility-depleted uranium, which is extremely dense, is fast replacing lead in many areas of technology-it seems likely that the Japanese will willingly repossess them along with the 